\title{
Martin de Barcos: grace, predestination, and Jansenism
}

Martin de Barcos (1600-78), is generally regarded as a second-rank figure in the history of Port-Royal, less prominent than his uncle, Jean Duvergier de Hauranne, whom he succeeded as abbé de Saint-Cyran, or Antoine Arnauld, or Pierre Nicole, let alone the subject of this conference, Blaise Pascal. ${ }^{1}$ SainteBeuve observes that, after his uncle's death, he never expressed a fundamental view ('sentiment essentiel') or a practical recommendation ('conseil de circonstance') that went unchallenged by his colleagues. ${ }^{2}$ Having mentioned the controversy, of which more presently, occasioned by the posthumous publication of the Exposition de la foy de l'Eglise romaine touchant la grâce et la prédestination, Sainte-Beuve remarks that Barcos 'avait la plume un peu fâcheuse, c'est-à-dire qui allait tout au travers aux endroits délicats, en était venu à ne plus pouvoir composer un seul écrit sans donner prise par mille saillies de doctrine' (I, 393). The Dictionnaire de Port-Royal provides a detailed biography, but does not discuss his theology or his personality as such. ${ }^{3}$ The main exception to this view is Lucien Goldmann, of whose interpretation of Jansenism Barcos is the keystone. For, (so Goldmann thought) he embodied the radical current of Jansenism, the full-scale tragic vision, articulated in Pascal and Racine but diluted in the more prominent exponents of the doctrine, Arnauld and Nicole. ${ }^{4}$ But even Goldmann says that 'Martin de Barcos ne fut ni un grand penseur ni un grand écrivain' (1).

None the less, he has some claim on our attention, especially in connection with Pascal, even if we do not accept Goldmann's account of their relationship. For we are told by Nicole that, although Pascal was 'la personne du monde le plus roide et le plus inflexible pour les dogmes de la grace efficace', he would say that, if he were to set about expounding the matter, he would hope to 'rendre cette doctrine si plausible, \& de la dépouiller tellement d'un certain air farouche qu'on lui donne, qu'elle serait proportionnée au goût de toutes sortes d'esprits'; and that, had his health permitted, he would have tried to 'rendre toutes ces matieres si plausibles \& si populaires, que tout le monde y auroit entré sans peine'. ${ }^{5}$ Now Barcos attempted something comparable in his Exposition de la foy de l'Eglise romaine touchant la grâce et la prédestination. Indeed, the early twentieth-century Catholic Encyclopedia, not by any means a sympathetic source, says that the Exposition 'may be looked

\footnotetext{
${ }^{1}$ I wish to thank the organizers of the conference, Richard Parish and Martine Pécharman, for their invitation to give the original paper of which this is a revised version, and the journal's reader for a number of acute and helpful observations. I would also like to thank Stephen Hampton for sharing his vast expertise in early modern theology.

${ }^{2}$ Charles Augustin de Sainte-Beuve, Port-Royal, II.ii.13, ed. Philippe Sellier, 2 vols (Paris:

Laffont, 2004), vol. I, p. 391.

3 'Barcos, Martin de', in Jean Lesaulnder and Antony McKenna (eds), Dictionnaire de Port-Royal

(Paris: Champion, 2004), pp. 143-5.

Dictionnaire de Port-Royal

${ }^{4}$ See the introduction to Correspondance de Martin de Barcos, abbé de Saint-Cyran, avec les abbesses de Port-Royal et les principaux personnages du groupe janséniste, ed. Lucien Goldmann (Paris: PUF, 1956), pp. 1-20.

${ }^{5}$ Pierre Nicole, 'Discours qui peut servir de préface', Traité de la grâce génerale, 2 vols (Paris: J. Fouillou, 1715), I, 2-3.
} 
upon as the official exposé of Jansenism'. ${ }^{6}$ Of course, as its title suggests, it represented itself not at all as expounding a distinct doctrine identifiable as Jansenism, but as a restatement of traditional Catholic teaching: the name of Jansenius never appears in it. I want to discuss the text's relation to the concept of 'Jansenism'. But, since its project of expounding the true Augustinian doctrine of grace coincides with that of Pascal in the Écrits sur la grâce, I shall also discuss the similarities and dissimilarities between Barcos and Pascal's handling of the theological issues.

Much light is thrown both on the origins and the reception of the Exposition in additional material provided in the edition of the text published along with Arnauld's Instructions sur la grâce in $1700 .{ }^{7}$ Here it is stated that the Exposition was commissioned by Bishop Pavillon of Alet, one of the most prominent Jansenist sympathizers among the episcopate, to serve as a textbook in his diocesan seminary. So far from thinking that it was best to leave the faithful ignorant of theology, Pavillon believed that they could not practise sound piety without an understanding of the true doctrines of grace and predestination. He therefore got Barcos to write the Exposition. ${ }^{8}$ A cleric who had been in the seminary of Alet and who possessed a copy for his private use, thought it should be published. (This must have taken place many years after the deaths of both Barcos (1678) and Pavillon (1677).) The cleric had it published 'à Orleans comme on le croit', without giving the author's name, and stating in the preface that Pavillon should be considered the real author. ${ }^{9}$

Opposition was aroused, and the Chancellor, who at this time would have been Louis Boucherat, comte de Compans, had 6oo copies seized in Paris. The book was handed over to two Sorbonne doctors opposed to its views, to be censured, but other doctors heard of this and proclaimed it was just an accurate explanation of St Augustine's doctrine, which treated other views with moderation. Thus the plan to get the Sorbonne to censure it was abandoned, and the hostile party denounced the book to the then Archbishop (LouisAntoine de Noailles). He first referred it back to the Sorbonne, but was finally

\footnotetext{
6 'Martin de Barcos', in Catholic Encyclopedia, http://www.newadvent.org/cathen/o2292b.htm, accessed 31 October 2012.

${ }^{7}$ Antoine Arnauld, Instructions sur la grâce selon l'Écriture et les Pères; Martin de Barcos, Exposition de la foi de l'église romaine touchant la grâce et la prédestination, et plusieurs autres pièces sur ce sujet (Cologne: Pierre Marteau, 170o). The publication details are patently fictitious. All references to the Exposition are to this edition. Page numbers are given where possible in parentheses in the text. On the origin of the text, see the 'Avertissement', Exposition, pp. 345-50.

8 Barcos's correspondence contains what may be references to this project. The letter to Pavillon of 29 January 1673 mentions Pavillon's desire for a straightforward account of doctrine suitable for ecclesiastics and his own attempts to write something appropriate (Correspondance, p. 393); in the letter of 4 September 1676, Barcos thanks Pavillon for his approval of 'les papiers que je vous ai envoyez' (413; italics in original). The need to explain the theological issues to the faithful is asserted more than once in the text of the Exposition; see below.

${ }^{9}$ The bookseller's preface to the reader at the head of the volume ('Le libraire au lecteur') says in fact that the first edition was published at Mons in 1697 by Gaspard Migeot. The title of this first edition is in fact slightly different: Exposition de la foi catholique touchant la grâce et la prédestination.
} 
pressured into condemning it, which, according to the 'Avertissement', he would never have done, if he knew it represented Pavillon's views. ${ }^{10}$

In point of fact, the moving spirit behind the publication seems to have been Dom Gabriel Gerberon, the Benedictine partisan of Jansenism (1628-1711). It was he who produced the 'Remarques' on Noailles's condemnation, which, along with the text of the condemnation, are printed in the second edition of the text. ${ }^{11}$

So much, for the moment, for the genesis of the Exposition. The text itself follows a question-and-answer method, ideally suited for its purpose as a textbook, and naturally cites references to any number of scriptural and patristic passages in support of its doctrine. It explicitly forestalls the objection that such issues are best not put before the faithful. On the contrary, those without the knowledge of grace 'se nourrissent dans une fausse confiance qu' ils mettent dans leur justice, croians trouver dans leur fond tout ce qui est nécessaire pour fuir le vice, pour embrasser la vertu, \& pour s'acquitter d'une maniére irréprochable de toutes leurs obligations' (2). It is therefore incumbent on the clergy to preach the truth on this matter to the faithful, following in this the example of St Augustine (3-6). Similarly, to hide from the people the mystery of predestination is to encourage the arrogance of the Pelagians. In itself the mystery edifies and consoles; it causes scandal and disturbance only when proclaimed in the wrong spirit, to lead astray rather than instruct. It is not one of those mysteries only to be handled by the learned, and of which one can know nothing without detriment to Christian piety (228). The truths of grace and predestination are absolutely necessary to make us pray properly, to tame natural pride, to establish sincere humility, to preserve us from ingratitude to Redeemer, to make us dread the terrible justice of his judgements, and so forth. They must be taught to all Christians (228-9); and Barcos adopts various suggestions from Augustine (De dono perseverantice, XXII.57-62) as to how to preach them prudently and tactfully (229-30).

Pascal, as is well known, seeks to present the doctrines of Augustine as a via media between the errors of Calvin and Molina. The twofold reference to these writers is also a feature of Barcos's text. But Barcos is more concerned than Pascal to situate what he is saying with reference to a broad range of positions held by scholastic theologians, because his intended readership could be expected to be familiar or at least acquainted with these.

The doctrines Barcos expounds will be in their essence familiar to those who have read the Écrits sur la grâce. Rather than merely recapitulating them, I shall therefore focus on the way Barcos and his editors engage with the fact of the condemnation of the Five Propositions.

In his condemnation of the Exposition, Noailles represented it as merely restating a doctrine already condemned at Rome. ${ }^{12}$ The 'Remarques' that follow

\footnotetext{
10 'Avertissement', Exposition, pp. 345-9.

${ }^{11}$ Gerberon's role is discussed in Barcos, Correspondance, 35-8.

${ }^{12}$ Noailles's 'Ordonnance et instruction pastorale' is reproduced in Exposition, 351-68. After condemning the book as a restatement of the condemned propositions of Jansenius (352-5) he sets out what he represents as the orthodox doctrine on the issues (356-66). There is no space here to discuss this part of his text.
} 
the text in the 1700 edition challenge his ruling: however closely the Archbishop has had the Exposition examined, and examined it himself, this doesn't deprive other theologians of their right to pass judgement on it and even to oppose his, if they think it contrary to teaching of Church or 'injurieux' to those who teach and defend it. Those with the best knowledge of such matters and who have most closely studied Augustine and his disciples see the Exposition as containing only his pure doctrine. They are entitled to say so and not obliged to defer to the Archbishop (386).

But the 'Remarques' also prolong and adapt two key strategies of Jansenist polemic discourse. The notorious Five Propositions were already circulating before Innocent X's bull Cum occasione of 1653. They made their first appearance on a list of propositions (seven originally), which in July 1649 Nicolas Cornet, then syndic of the Sorbonne, claimed to have found in theses put forward by bacheliers, and which he invited the Faculty to condemn. (The 'Remarques' speak of Cornet as fabricating them (374)). The Augustinians' first response to the five propositions was to argue that they were ambiguous: they could be taken either in an orthodox or a heretical sense. ${ }^{13}$ The 'Remarques' maintain this view: the Five Propositions are ambiguous, containing a heretical sense, condemned by the whole Church, and the sense of St Augustine, which the Popes never intended to condemn (394-5). None the less, this line of argument was made more difficult to sustain by the promulgation of Cum occasione, which simply condemns the propositions, and does not distinguish between orthodox and heretical senses. At this point, a shift of terrain was necessary, and Arnauld invoked the distinction between fait and droit: the Papal condemnation of the content of the propositions, bearing on a matter of faith, is authoritative; but it does not settle the point of fact, as to whether the propositions are in fact in Jansenius's Augustinus; and in fact, argues Arnauld, they are not (Provinciales, 27). Pascal endorses this line in the first Provinciale (117-18). This twofold defensive manoeuvre was itself condemned in Alexander VII's Ad sanctam beati Petri sedem of 16 October 1656: the propositions are in Jansenius's book and they were condemned in the sense in which he maintained them. ${ }^{14}$ None the less, the 'Remarques' continue to maintain that the Five Propositions were never in the Augustinus, let alone in the sense condemned, and that they have never been discovered in the text in nearly fifty years since (Exposition, 374). But, more interestingly perhaps from our point of view, the 'Remarques' argue that the Exposition is unaffected by the condemnation of the Five Propositions.

To be sure, if Cum occasione is taken as condemning a body of doctrine through the condemnation of five representative propositions, then Barcos's doctrine does not escape scot-free, for in its substance it is identical to that of Jansenius and Pascal (who follows Jansenius very closely, as Philippe Sellier has

\footnotetext{
${ }^{13}$ See Blaise Pascal, Les Provinciales, ed. Louis Cognet, rev. Gérard Ferreyrolles (Paris: Classiques Garnier, 2010), pp. 20-1.

${ }^{14}$ See Enchiridion symbolorum, definitionum et declarationum de rebus fidei et morum, ed. Heinrich Denzinger, revised by Adolf Schönmetzer, S.J.,, consulted at http://catho.org 28.viii.13, §§ 2010-12 (hereafter DS).
} 
shown). ${ }^{15}$ But if it is taken as condemning specific propositions, or condemning them only in a particular sense, then the possibility emerges of maintaining the essential neo-Augustinian doctrine without falling foul of the condemnation. The 'Remarques' claim in effect that the Exposition realizes this possibility. Moreover, because, unlike the Provinciales, it does not commit itself to the defence of Jansenius by name, the Exposition can be seen as evading the explicit condemnation of Jansenius in Ad sanctam Petri sedem.

The 'Remarques', then, adapt to the Exposition the two strategies put into effect in the original defence of Jansenius. They discuss the Propositions in terms of a distinction between heretical and orthodox senses; and they deny that the Propositions themselves are to be found in Barcos's text.

The distinction between heretical and orthodox senses is mobilized in connection with the First Proposition, which runs as follows:

Aliqua Dei praecepta hominibus iustis volentibus et conantibus secundum praesentes quas habent vires, sunt impossibilia; deest quoque illis gratia, qua possibilia fiant. ${ }^{16}$

Some commandments of God are impossible to justified human beings willing and striving to the best of their available strength; moreover, these people lack the grace by which they would become possible.

First, as the 'Remarques' point out, the Exposition does not literally restate this claim (387). Secondly, the Proposition has both a heretical and an orthodox sense. If, then, the Archbishop's claim is that the Exposition upholds the heretical sense of the Proposition, let him explain in what this sense consists (388). Certainly, insofar as the Proposition maintains the doctrine that without efficacious grace we can do nothing it is impossible to reject it without clashing with the followers of SS. Thomas and Augustine, and renewing Pelagian heresy (389). The proposition that St Peter was deprived in the moment of his fall of the grace without which we can do nothing is in Augustine and Chrysostom (391).

The Proposition in short has two meanings. The first is as follows:

Qu'il y a des commandemens de Dieu qui sont simplement \& absolument impossibles aux justes mêmes, quelque bonne volonté qu'ils ayent, \& quelque effort qu'ils fassent pour les garder; \& qu'ils n'ont point de grace qui les leur rende possibles. (395)

This, say the 'Remarques' is contrary to Scripture, Augustine, and all the Fathers (395); and this is the heretical sense condemned by the Popes (395-6). However there is another possible meaning:

L'autre sens est, qu'il arrive quelquefois que des justes même, qui ont quelque volonté, mais imparfaite, \& qui font quelque effort, mais trop

\footnotetext{
${ }^{15}$ On the closeness of Pascal to Jansenius, see Sellier, Pascal et saint Augustin, $2^{\text {nd }}$ edn (Paris: Albin Michel, 1995 [1st publ. 1970]): see, e.g. pp. 336-7, 347.

${ }^{16}$ The text of the Propositions can be found in DS, §§ 2001-5. Translations are mine. 'Justified' has the general sense of being in a state pleasing to God (prior, that is, to the failure to keep the commandments).
} 
foible; n'ont pas alors un pouvoir entier \& prochain de garder quelque Commandement de Dieu: la Grace \& le secours qui leur devroit donner ce pouvoir prochain \& achevé, ne leur étant pas donné. (396)

This is Catholic doctrine, and clearly not condemned (396). In fact Barcos himself, in the body of the text, argues that the commandments are possible not only to just, but even to sinners, since they can always fulfil them with the help of grace, and quotes the Council of Trent in support of this view (186-7).

On this showing, say the 'Remarques', Barcos can't be accused of holding the First Proposition (396-7); for to say that some commandments are impossible even to the just who wish and strive to fulfil them this is not the same as saying what he does say, that some of the just in some circumstances lack the necessary grace to avoid falling into mortal sin (398).

At this point the reader might be feeling confused. Which of the strategies is being mobilized here? Is the claim that Barcos upholds the First Proposition, but in an orthodox, not a heretical sense? Or is it that he does not uphold it at all? It seems that the 'Remarques' are operating with two different modes of analysis. First, referential: that is, a proposition can be taking as alluding to and summarizing some existing doctrine; second, verbal: it can be viewed as an autonomous verbal construct. (Pascal makes a similar distinction between examining the meaning of a proposition (in this case a pronouncement of the Council of Trent) 'par les simples termes' and examining it in view of 'l'objet qu'ont eu les Pères et le concile en faisant cette décision' ${ }^{17}$ ) From the former point of view, the First Proposition could be taken to be conveying either a heretical (hardline Protestant) position and an orthodox Catholic position. It could be read as an argument a fortiori for the Protestant view: it is absolutely impossible for human beings to fulfil the commandments, because even the justified cannot be sure of doing so, however much they want and try to. But this is not, say the Augustinians, what a Catholic theologian means when he points to the betrayal by Christ of St Peter, as an indication that the just are sometimes unable to fulfil the commandments: for he denies the Protestant's basic assumption that the commandments are intrinsically impossible. Now, the Papal condemnation cannot possibly apply to the orthodox Catholic position. It must therefore be aimed at the Protestant view. Here then the line of defence is that Barcos upholds the orthodox doctrine. Secondly, his position is to be measured against the letter of the Proposition. The proposition refers to the inability to fulfil the commandments of 'hominibus iustis volentibus et conantibus, secundum praesentes quas habent vires', which appears to mean that they fail to fulfil the commandments, however much they wish to and however hard they try to. But from Barcos's point of view, the justified who fail to fulfil the commandments are wishing and trying indeed, but only feebly. So they do not come under the scope of the Proposition.

\footnotetext{
${ }^{17}$ Pascal, Écrits sur la grâce, II, in CEuvres complètes, ed. Michel Le Guern, 2 vols, Bibliothèque de la Pléiade (Paris: Gallimard, 1998-200o), vol. II, p. 221. All subsequent references are to this edition.
} 
Moreover, the 'Remarques' go on to argue, none of the other four propositions is to be found in the Exposition (402). I shall run through them briefly, and then examine each point in more detail. Take the Second Proposition: 'Interiori gratiae in statu naturae lapsae nunquam resistitur' (in the state of fallen nature there is no resisting interior grace). Barcos shows that we do resist inner graces of the understanding and weak graces of the will; and that we even struggle against strong graces of the will, even if we don't resist them in the sense of overcoming them. Also we resist grace by ruining its effect through $\sin (403)$. The same reasons apply to the Fourth Proposition:

Semipelagiani admittebant praevenientis gratiae interioris necessitatem ad singulos actus, etiam ad initium fidei; et in hoc erant haeretici, quod vellent eam gratiam talem esse, cui posset humana voluntas resistere vel obtemperare.

The Semi-Pelagians admitted the necessity of a prevenient interior grace for particular acts, and even for the beginnings of faith; and they were heretical in this respect, that they wanted this grace to be such that the human will could resist it or comply with it.

This is not Barcos's view, for he does not think that it is heretical to hold that the human will can resist grace (405-6); on the contrary, he agrees that it can. The issue of the Third Proposition is human freedom:

Ad merendum et demerendum in statu naturae lapsae non requiritur in homine libertas a necessitate, sed sufficit libertas a coactione.

In order to be able to merit or demerit in the state of fallen nature, it is not necessary that human beings should possess freedom from necessity; freedom from coercion is sufficient.

Barcos shows that the strongest efficacious grace does not jeopardise, but actually strengthens our freedom. Moreover, he connects our meriting and demeriting in this state with liberty of indifference, in the sense of having the power to resist grace even when under its influence (404). He shows that the will, though determined by grace, acts freely, not by necessity; an absolute necessity, which removed the power to resist the good to which grace conveys us would be contrary to freedom as we possess it in this state. Moreover, there is a sense in which we can be said to possess liberty of indifference, in both its forms, namely contrariety and contradiction; and this is a proof of our freedom. He does not, then, reduce freedom to absence of coercion, as does the Third Proposition (405). ${ }^{18}$

\footnotetext{
${ }^{18}$ The two kinds of indifference are glossed in the body of the text: 'l'indifférence au bien \& au mal, qu'on appelle indifférence de contrarieté, \& l'indifférence à agir ou à ne pas agir, qu'on appelle indifférence de contradiction' (222): the passage is quoted on p. 405. That is, I have indifference (or liberty) of contradiction if I am free both to perform and to refrain from a given act (whether good or bad); indifference (or liberty) of contrariety if I am free to perform either a morally good act or a bad one.
} 
What of the Fifth Proposition, 'Semipelagianum est dicere, Christum pro omnibus omnino hominibus mortuum esse aut sanguinem fudisse' (it is SemiPelagian to say that Christ died or shed his blood for all human beings whatever)? Barcos, the 'Remarques' point out, most certainly does not hold that it is a Semi-Pelagian error to say Christ died for all human beings. ${ }^{19}$ In fact, he says it would be odious to claim that Christ did not die for all (407; cf. 205). Jesus died not only for the predestined but also for the reprobate (408). Therefore, in sum, Barcos cannot be accused of renewing the heresy of the Five Propositions (408-9).

So much for the defence of Barcos in the 'Remarques'. Let us now look at his arguments in more detail, so as to exhibit the underlying issues more fully.

Barcos's aim, in his discussion of the possibility of the commandments (the subject of the First Proposition) is to confute the theory, which he would call Molinist, that all human beings receive sufficient grace to observe the commandments, or to pray for the help to do so, and that, if they do not fulfil the commandments, this is because they have chosen to reject this grace. An argument in favour of the Molinist view is that, if all do not have sufficient grace, this means that the commandments are impossible to those to whom God does not give the grace to accomplish them (186). If this is so, how can sinners be morally responsible for their failure to obey the commandments?

Barcos rejects this line of argument. Augustine says that the commandments are possible not only to the just, but to the greatest sinners, for though God commands what man cannot perform with all his natural powers, man can perform it with the help of grace (186-7). If God commands us to do what in a given situation we can't do, and doesn't in that situation give us the grace to fulfil his commandments, he does so in order that we will make the effort to obtain grace.

To say that God does not give everyone sufficient grace to accomplish the commandments is by no means verging on Calvinist heresy (187). For Calvin teaches that the commandments are impossible, even with grace:

Calvin dit que les plus justes (lesquels dans son sens ne sont tels que par une justice qui leur est imputée, \& non pas par une justice véritable) transgressent sans cesse la Loi de Dieu, \& qu'ils ne peuvent l'accomplir, parce qu'ils pechent mortellement en toutes leurs actions: au lieu que l'Eglise enseigne que les Justes accomplissent vraiment les Commandemens de Dieu, quoiqu'elle reconnoisse qu'il y en a qui sont quelquefois dans l'impuissance d'en accomplir quelqu'un. (188)

The Catholics, therefore, deny that the commandments are impossible. First, because 'impossible' does not mean 'what some people cannot do', but means 'impossible in any circumstances, even with help of grace' (188-9). Many

\footnotetext{
${ }^{19}$ Barcos uses the unusual term 'Demi-' rather than the more usual 'Semi-Pelagian'. The concept of Semi-Pelagianism, widespread in early modern theological debates, is a late-sixteenthcentury creation (Anthony Levi, Renaissance and Reformation: The Intellectual Genesis (New Haven and London: Yale University Press, 2004), 34, 378 n. 24). Alister McGrath calls it 'a seriously misleading anachronism' (Iustitia Dei: A History of the Christian Doctrine of Justification, 3rd edn (Cambridge: Cambridge University Press, 2005), 95).
} 
things are impossible to some, yet possible to others, or can be done if we have some assistance, without which we cannot do them. Thus St Thomas says that we cannot love God, or believe the articles of faith, without the help of grace: but these things are not impossible because we can do them with the help of grace, even though it is not given to all. Secondly, because 'Dieu ne nous commande rien que nous ne puissions observer si nous voulons' (189). In support Barcos quotes Augustine's claim that we can observe the commandments if we want to. ${ }^{20} \mathrm{~A}$ thing is in our power when we do it if we will to do it, and do not do it if we do not will to do it. The will, of course, must come from God (189).

So when it is said that man cannot fulfil the commandments without grace what this means is that 'il n'a pas tout ce qui est absolument necessaire de la part de Dieu pour les accomplir effectivement', i.e. he lacks the efficacious grace. This does not mean he is absolutely powerless, for the power to fulfil the commandments remains within human nature, which has not been destroyed by $\sin (190-1)$. It is identical with the will, which is intrinsically flexible: 'Par ce pouvoir on n'entend autre chose que la volonté de l'homme qui est flexible \& se peut porter où elle veut' (191). But such a power is insufficient to do good without the aid of grace (191).

Those who do not have 'tout ce qui est necessaire de la part de Dieu pour accomplir les Commandemens' are still culpable for not observing them. (191). Their lack of grace must be imputed to them. They themselves deprived themselves of this help, 'qui ne leur est refusé qu'en punition de leurs pechez précedens, ou au moins du peché originel' (191-2).

But this seems to clash with the established maxim that no one is obliged to do what is impossible ('ought', as Kant remarked, 'implies can'). We must, however, says Barcos, distinguish two kinds of impossibility or powerlessness ('impuissance'). One is external in origin: we lack something outside ourselves, however strongly we want it. If confined in a house by violence, one can't go to mass; if one has no money, one can't give alms. The maxim applies in these cases, and God takes the will for the deed (192). The other kind is internal: it comes 'du défaut de la volonté, de sa dureté \& de son obstination' (192-3). In sinners, this is a result of their sins.

Toute la raison pour laquelle ils ne peuvent pas observer les commandemens de Dieu, c'est qu'ils ne le veulent pas; \& ils ne le veulent pas parce que leur volonté est obstinée dans le mal, \& qu'elle est toute dépravée; \& cette dépravation \& obstination sont volontaires en eux, ils les aiment, \& ils se plaisent d'y demeurer. (193)

This kind of powerlessness can serve as no excuse when it prevents them from fulfilling commandments.

But why then does God give commandments to those to whom he will not grant the grace to fulfil them? First, says Barcos, rather surprisingly perhaps, to show us that it is not grace alone that acts in our salvation, but 'qu'il y a en nous une liberté, sans le vouloir \& l'action de laquelle il n'est pas

\footnotetext{
${ }^{20}$ 'Certum est nos mandata servare, si voluerimus' (Augustine, De gratia et libero arbitrio, XVI.32 (PL 44, 900)).
} 
possible d'accomplir ce qui est commandé'; secondly, to render man inexcusable in his own eyes, and strip him of the pretext of ignorance (193).

Comme Dieu ne fait rien que pour ses Elûs, le grand dessein qu'il a en donnant ses Commandements à des pecheurs endurcis \& qu'il a abandonnez, c'est de faire que ceux qui sont à lui par son élection éternelle, en profitent' (194).

They will learn that external graces are nothing unless an 'onction intérieure' changes and renews the heart (194).

There are in fact two ways in wich the just sometimes lack the necessary grace to fulfil the commandments. First, they do not have all the grace necessary to accomplish all the commandments so perfectly as not to transgress them in any way, even venially-otherwise it would be possible to live without sin, contra I John 1.8-10. Secondly, some (not all) of the just sometimes lack the grace necessary to avoid falling into mortal sin. Otherwise, anyone once justified would be certain to persevere, and this clashes with St Paul's warning 'Que celui qui est debout, doit craindre de tomber' ('let him that thinketh he standeth take heed lest he fall') (I Cor. 10.12). But while the just man remains just, he always has the necessary grace to fulfil the commandments, because he is actually fulfilling them. That is to say, righteousness consists in actually fulfilling the commandments: it is not, as in the Lutheran and Calvinist conception, merely imputed to an agent who fails in fact to fulfil them (195).

How about a possible compromise? Suppose the just do not always have sufficient grace to act: might it not be that they have sufficient grace to pray for the help they lack (this point of view is debated in Provinciales, I?)? No, says Barcos, because prayer demands grace no less than action. The faithful need efficacious grace both to pray and to act. 'En l'un \& en l'autre il faut que ce soit l'Esprit de Dieu qui forme dans eux le mouvement même de la volonté, par lequel ils agissent \& par lequel ils prient' (196). The alternative to this view is Semi-Pelagianism, because if you allow everyone the grace of prayer, you make them masters of their own salvation. Unbelievers, incidentally, do not have the grace of prayer, because they are incapable of any grace whatever (196).

The Second and Fourth Propositions deal with the resistibility of grace. Barcos notes that the Council of Trent had anathematized the view that grace cannot be resisted. ${ }^{21}$ Its target, as he says, was Luther and his followers, who allegedly make grace necessitating, 'en sorte que le libre arbitre est purement passif, \& ne fait que recevoir son action par une impression étrangere et violente comme un instrument inanimé'. ${ }^{22}$ Trent declares on the contrary:

que le libre arbitre fait le bien, parce qu'il le veut faire; \& que lors même qu'il le veut faire, il a le pouvoir de ne le pas vouloir; car quoique la grace qui nous est donnée, nous ôte la volonté de résister, elle ne nous ôte pas néanmoins le pouvoir. (171)

\footnotetext{
${ }^{21}$ See DS 1554, 1525 .

${ }^{22}$ Calvin explicitly denies this interpretation of his position (Institution de la religion chrétienne (1541), ed. Olivier Millet, 2 vols (Geneva: Droz, 20o8), ch. II, vol. I, p. 334).
} 
But the Second Proposition does not say that interior grace cannot be resisted; it says that it is never resisted. Does Barcos hold this view?

First, he points out that we indubitably sometimes resist external graces (171). As for the internal variety, the answer is: 'It depends.' If they are 'graces de l'esprit' (good thoughts, illuminations), they can be resisted because (like external graces) they do not act on the will. If 'graces de volonté', it depends on whether these are weak or strong.

Pour celles qui sont faibles, on y résiste, de telle sorte néantmoins, qu'on n'arréte pas leur effet prochain \& immédiat, quoiqu'on empêche celui qu'elles devroient avoir, si elles trouvoient un sujet en qui il y eût moins d'obstacles. (172)

This shows that it is erroneous to say 'qu'on ne lui resiste jamais dans l'état de la nature corrompuë'. Barcos, then, explicitly denies the Second Proposition.

'Mais si ces graces sont fortes', he adds, 'elles ont toûjours leur entier \& dernier effet'. And this is true even with hardened hearts, because such graces take away their hardness (172). They cannot be resisted in the sense of prevented from taking effect. But there can be resistance in the sense of opposition on the part of the will, owing to cupidity. Hence the struggles of which S. Paul speaks. This resistance is clearest as regards the initial grace, which finds our heart in a fundamentally contrary disposition of aversion from God, attachment to creatures. One can also resist grace by a change of disposition and will, ruining its effect by $\sin (173)$. The will is always mutable, and thus may wish not to persevere. Otherwise none of the faithful would lose the faith or be overcome by concupiscence, as St Prosper points out (174). The infallibility of the effect of efficacious grace thus does not imply the impossibility of resistance. So much for the Second Proposition. If the Fourth is taken (as the 'Remarques' take it) as essentially claiming that it is heretical to speak of grace as depending on human consent, then one could indeed see the same considerations as justifying the claim that Barcos does not endorse it.

The Third Proposition deals with the nature of the human freedom required for moral responsibility. Barcos maintains 'que la Grace qui fait vouloir $\mathcal{E}$ faire le bien, ne blesse en rien la liberté' (212: italics in original). In fact, so far from diminishing, grace perfects freedom, since man's will is never freer than when grace gives him the help necessary to do good \& avoid evil (212). ${ }^{23}$

But if grace determines the will, how can it not violate liberty? According to Goldmann, one of the marks of Barcos's radicalism is his rejection of Thomism and Cartesianism, whereas Arnauld and Nicole make concessions to the former and espouse the latter. ${ }^{24}$ But in fact Barcos quotes the Thomist answer to this question with apparent approval. The Thomists claim:

que la Grace faisant cette détermination, \& agissant sur la volonté pour avoir son consentement, lui laisse le pouvoir de refuser; de sorte que la volonté produit tellement son action, qu'elle la peut suspendre \& ne la produire pas; encore qu'il n'arrive jamais que la Grace opérant sur la

\footnotetext{
${ }^{23}$ Whether this response is entirely pertinent is discussed below.

${ }^{24}$ Barcos, Correspondance, 9-11; cf. p. 6.
} 
volonté, cette même volonté résiste \& ne suive pas son impression. (213)

The power of the will to refuse its consent comes partly from its intrinsic flexibility to evil, but mainly:

de ce poids, de cette inclination \& de cette pente que nous avons au peché par la concupiscence, qui fait qu'il y a en nous une puissance de pecher tres-cachée, qui demeure toûjours dans l'homme, non seulement quand il est privé de la suavité de la Grace, mais même lorsqu'elle le ravit à lui-même par ses charmantes douceurs. (213-14).

Augustine reconciles freedom and grace another way in his dispute with the Pelagians: instead of ruining freedom, as they claim, he contends that grace establishes, fortifies, and perfects it.

Car si être libre, c'est avoir ses actions en sa puissance, c'est les faire quand on veut, il s'ensuit que la Grace qui nous donne la volonté, en nous faisant vouloir le bien, \& nous le faisant vouloir fortement, nous donne aussi la véritable liberté, ce qu'elle fait en nous délivrant de la servitude de la concupiscence dominante, qui nous retient $\&$ nous empêche de nous porter au bien. (214-15)

The reason it is so widely believed that efficacious grace clashes with freedom is 'une fausse notion de la liberté' which conceives it as:

une certaine indifférence par laquelle on veut que de quelque côté que se porte la volonté, ou du côté du bien, y étant attirée par la suavité de la Grace; ou du côté du mal, y étant entraînée par la mortelle douceur de la concupiscence, elle se trouve dans un équilibre qui fait qu'elle se peut tourner indifféremment vers le bien ou vers le mal: en sorte que lors même qu'elle est poussée par la Grace, ou emportée par la concupiscence, elle est toûjours en état de faire actuellement l'un ou l'autre, à raison de la flexibilité qui lui est naturelle. (215)

The Pelagians insisted that such indifference is necessary to liberty (Barcos no doubt intends the reader to make the connection with the Molinists, who held the same): but Augustine denies that this is so.

Elle [cette indifférence] a toûjours été rejettée par saint Augustin, comme contraire au véritable sentiment qu'on doit avoir de la grace de Jesus-Christ, laquelle déterminant la volonté au bien, l'empêche de refuser son consentement, ou de vouloir se porter au mal, quoiqu'elle ne lui ôte pas la puissance de l'un \& de l'autre. (215-16)

Although Barcos seems to be saying that Augustine rejects the very notion of indifference, this is not quite what he means. He means that Augustine denies (a) that indifference is essential to freedom; and (b) in particular, that the will under the influence of grace or concupiscence is indifferent, in the sense of equally disposed to respond or not to respond to it (215-16). But Barcos does not reject the notion of indifference altogether. A certain kind of indifference is an inseparable companion of freedom in our present fallen state. But it is not a positive power of self-determination to either 
one of two contraries, to use an expression of Descartes', ${ }^{25}$ or, in Barcos's words, 'une certaine disposition de l'ame qui fasse qu'elle se tourne où elle veut, comme aiant toûjours tout ce qui lui est nécessaire pour se déterminer ellemême à ce qu'il lui plaira'. It consists in the fact that the will, even when under the influence of grace, always has the power to resist and not to do the good to which grace is applying it, or even to do the contrary evil, even though it will never actually do so, while under the influence (216). ${ }^{26}$ Such indifference is inseparable from freedom (and merit or demerit) in the state of corrupted nature: but it is far from essential to freedom as such (217). For as the will is fortified and established in the good, so this kind of indifference is diminished, 'l'homme n'étant jamais plus libre que quand il se porte au bien avec moins de résistance' (217-18). Which shows that indifference of this kind not essential to freedom; else it would grow as freedom grows (218). It will not exist in heaven, when the will will be freest (221).

But how can grace not jeopardise freedom when it seemingly necessitates the will, pushing and determining it to what it (grace) wills? To this question Barcos replies:

Il n'est pas vrai qu'elle nécessite la volonté, elle ne lui fait aucune violence, elle ne la contraint nullement d'agir contre son gré; parce qu'en même temps qu'elle la fait agir, elle lui donne non seulement le pouvoir d'agir, mais aussi de le vouloir, \& de le vouloir d'autant plus fortement que la Grace est plus forte \& plus puissante: de sorte que bien loin que la volonté soit plus libre quand elle résiste à la Grace, pour être encore retenuë par la délectation charnelle de la concupiscence qui est souvent plus ardente \& plus enflammée que la charité; au contraire elle ne l'est jamais davantage, que quand elle est plus assujetie \& plus dans la dépendance de cette même Grace. (218-19)

Does not the will so influenced, however, act by necessity? Barcos's answer involves careful distinctions. If by 'necessairement' you mean 'que la volonté agisse par une necessité involontaire qui la force, la contraint \& lui fait faire ce qu'elle ne veut pas', no. The will cannot be forced to want what it wants: 'elle le veut toujours volontairement' (219). ${ }^{27}$ If you mean 'une necessité absoluë qui mette la volonté dans une fermeté immuable', again no, because in the state of corrupted nature there are always the dregs of concupiscence, hence the power to resist (even if never the fact) (219-20). If you mean 'une necessité qui laissant le pouvoir à la volonté de refuser son consentement, fait néanmoins qu'elle suive l'impression de la grace', then, yes (220).

The second kind of necessity mentioned above (being immutably established in the good and unable to turn to evil) is contrary to freedom in our present corrupted state: but not essentially, though. The blessed are free,

\footnotetext{
25 'Positiua facultas se determinandi ad vtrumlibet e duobus contrariis' (Descartes to Mesland, 9 February 1645 (AT IV, 173)).

${ }^{26}$ Plainly Barcos thinks that Augustine would accept indifference in this sense: see the passage quoted above in which he says that grace, for Augustine, leaves the will the power to refuse its consent (215-16).

${ }^{27}$ Barcos refers here to Augustine, De civitate Dei, V.10.
} 
though they love God necessarily and immutably, because their adherence to God

ne vient pas d'une impression étrangere, ni d'un instinct \& d'un mouvement indélibéré, mais du choix tres-libre de leur volonté, qui veut suivre leur droite raison, laquelle leur fait juger, mais avec un jugement pur, tranquille \& parfait, que Dieu est infiniment aimable. (221)

This necessity perfects, rather than destroying, their freedom (221). It eliminates indifference, but not liberty, for the reason we have seen. To be free, in short, it is sufficient that one is not acting from constraint or from an involuntary necessity (223). In saying this, however, Barcos comes close to restating the Third Proposition, which equates liberty with absence of coercion. I shall return to this point.

The definition of freedom as absence of coercion is purely negative. But for Barcos freedom has a positive content also.

Elle consiste à avoir ses actions en sa puissance. La liberté n'est autre chose que sui potestas; être libre c'est être maitre de ses actions, c'est les faire quand on veut, car elles ne sont en notre puissance, qu'entant qu'elles se font aussi-tôt que nous le voulons; or il n'y a rien qui soit plus en nôtre puissance que nôtre volonté même, \& par consequent il n'y a rien de plus libre que la volonté. $(223-4)^{28}$

But we act most voluntarily, and hence most freely, when under the influence of grace:

L'homme n'agissant jamais avec plus de joie \& avec plus de plaisir, \& par consequent avec plus de volonté que lors que la Grace forme en lui la bonne volonté, que lorsqu'elle fond la dureté de son cœur par la douceur de son amour, que lorsque par sa force toute-puissante elle opére en lui le consentement, que lorsqu'elle l'incline, qu'elle le pousse, qu'elle de détermine, qu'elle le ravit, qu'elle l'emporte, \& qu'elle l'aplique à vouloir le bien; jamais aussi il n'a une plus véritable \& plus entiére liberté. (225).

In the light of this, are the 'Remarques' justified in claiming that Barcos has not fallen foul of the condemnation of the Third Proposition? He might seem to agree with it in so far as he equates freedom with absence of coercion. But, in Barcos, this is a statement about freedom in general, applicable to the blessed in heaven, as well as to human beings in this life. In this life, however, our freedom is always accompanied by indifference, albeit of a limited kind. It is therefore more than absence of coercion. It could therefore be argued that he does not share the conception of freedom of the implied author of the Third Proposition; at least, that is a defence that could be mobilized on his behalf.

It is not, perhaps, however, fully adequate as it stands. Here a distinction comes into play. The Proposition mentions merit or demerit, but how we

\footnotetext{
${ }^{28}$ This conception of freedom is Augustine's: see, for instance, De libero arbitrio, III.iii.8 (PL 32, 1275); De spiritu et littera, XXXI.53 (PL 44, 234-5).
} 
interpret it depends on which we emphasize. Barcos and the author of the 'Remarques' seem to be focusing on merit and therefore to be reading the Proposition as follows: man cannot merit without grace; but grace (efficacious grace, that is) imposes necessity, since we have no power to choose whether to accept it or not; however, this does not take away free will, because free will is suppressed only by coercion. Barcos, however, emphasizes that grace does not impose necessity, in the most obvious sense, and in fact enhances freedom. Consequently, from this point of view, he is not endorsing the condemned Proposition. But the Proposition also mentions demerit: and I think one can suggest this is actually the more important term, and that the prime issue involved here is not the effect of grace on the will (which subject is treated in the Second and Fourth Propositions). The condemnation of the Proposition may be directed rather at Jansenius's claim that fallen man without grace lies under a general necessity of sinning, yet retains free will (and the capacity to merit or demerit) insofar as he does not act under compulsion. ${ }^{29}$ To dissent substantively from that one would need to explain, not only how the person moved by efficacious grace retains a certain indifference (residual concupiscence), but what kind of indifference might be possessed by the performer of a sinful act. Barcos does not investigate this point, although one can imagine an argument that runs like this: you committed fornication because you willingly succumbed to concupiscence (no one was forcing you), yet you could in a sense have refrained from it, if you had wanted to, because you knew it was wrong. Or, you refrained from fornication, and thus materially accomplished an act of chastity, though you did so only because your pride persuaded you to do so, so you were indifferent in the sense that there was a pull from both directions, rather than a single overmastering urge. ${ }^{30}$

Barcos's engagement with the issue raised by the Fifth Proposition (whether Christ died for the sake of all human beings) is, as with the First, motivated by his desire to reject the thesis of a universal sufficient grace. If Jesus died to redeem all human beings (as 1 Timothy 2.6 implies), does it not follow that his sacrifice would be vain if God does not give all human beings a chance of redemption? Barcos denies the inference: that Jesus's death was sufficient to redeem all human beings, does not mean that in fact it benefits them all (204). 'Il est certain que Nôtre Seigneur n'a point eu une volonté formelle de mourir pour tous les hommes; c'est-à-dire, de faire part à tous du mérite de sa mort' (205). Otherwise how to explain that he lets so many children perish without baptism, despite their parents' and priests' efforts; that he lets unbelievers perish in darkness, since he prevents the Gospel being preached to them (205-6)? I pass over Barcos's exegesis of the key passages in St Paul to his summary of the essential points at issue. We should not say 'que Nôtre Seigneur soit mort pour mériter des Graces suffisantes qui soient

\footnotetext{
${ }^{29}$ Jansenius, Augustinus (Rouen: Jean Berthelin, 1643), vol. II, De statu lapsce naturce, IV.19-21, pp. 259-64.

${ }^{30}$ This analysis of apparent (but false) virtue being produced by a struggle between rival cupidities can be found in Jansenius: see, e.g. De statu lapsce naturce, III.20, p. 214 (its source is Augustine, De civitate Dei, V.13). Jansenius accepts indifference in the limited sense explained here: De statu lapsce naturce, IV.19, p. 259.
} 
données \& à tous les hommes, \& qui leur soient soumises pour en faire tel usage qu'il leur plaist; en sorte qu'il ne dépend que d'eux de croire, \& de pratiquer toutes les œuvres necessaires pour parvenir au salut' (212). But we may say that Jesus died for all human beings in these senses: infected);

1. He died for a cause common to all, the sin with which they are all

2. His death was sufficient ransom for all;

3. He died for all kinds of people;

4. He died for all the faithful, in so far as they all receive some fruit of his death. Several of the reprobate receive graces merited by his death (211-12). So it is not true that he died only for the salvation of the predestined, a view justly condemned (211). On this showing, Barcos is rejecting the labelling of the view that Christ died for all human beings as semi-Pelagian: consequently, he dissents from the Fifth Proposition.

What follows from all this? It seems, first of all, that Gerberon (if he is the author of the 'Remarques') has presented a fair account of Barcos's views. If, then, 'Jansenism', then, is regarded (as its enemies regarded it) as a heresy consisting in doctrines summarised in the Five Propositions, then Gerberon seems justified in claiming that the Exposition does not fall foul of the condemnation of 'Jansenism'. Barcos does not, to be sure, explicitly discuss the question of the Propositions' presence in or absence from the text of the Augustinus; and the name of the Bishop of Ypres never appears once in the Exposition. But his discussion of several of the questions involved suggests that he was being careful to protect his text from accusations of 'Jansenism' based on the condemnation of the Propositions. Sainte-Beuve's remarks about Barcos's clumsiness of expression on points of doctrine seem, in this light, rather unfair. Whether the defence is altogether convincing is another question: it may well be the case that there is a substantial difference between the Jansenist position on the impossibility of the commandments and that of the Lutherans and Calvinists, but it seems hard to deny that the condemned First Proposition refers to the former, rather than the latter.

A few remarks in conclusion as to the relation between Pascal's Écrits sur la grâce and the Exposition. Barcos's patient catechetic exposition has none of the intellectual brilliance of Pascal's work. Pascal seeks to be faithful to the teaching of Augustine while radically rethinking its basic categories. This appears from passages like the brilliant analysis of levels of agency in the seventh Écrit (257-9) or of dual relationships in the first:

Il ne faut que remarquer qu'il y a deux manières dont l'homme recherche Dieu; deux manières dont Dieu recherche l'homme; deux manières dont Dieu quitte l'homme; deux dont l'homme quitte Dieu; deux dont l'homme persévère; deux dont Dieu persévère à lui faire du bien. $(E G \mathrm{I}, 218)$

But it would be entirely wrong to present this contrast as if Barcos were merely a foil for Pascal's genius. Had he been capable of such an intellectual effort as Pascal's, he would no doubt have eschewed it as self-assertion, succumbing to the libido sciendi (this is not to say he would have regarded 
Pascal's own efforts in this light). God has declared the truth in the Bible, and in the interpretations of the Fathers, ratified by the Church as definitive statements of its teaching: who are we to try to improve upon their formulations?

As regards the major theological issues, there are no surprises here: the doctrines expounded by Barcos are essentially those upheld by Pascal. To take a couple of examples: Pascal too argues, as regards the possibility of the commandments, that what Trent condemns is the view that they are intrinsically impossible to the just, whereas the view that he upholds is that they are sometimes so. ${ }^{31}$ Like Barcos again, Pascal contends that in a sense we always have the possibility of observing the commandments, since if we wanted to fulfil them, we could do so. What we do not have is an effective power, since we cannot want to fulfil them without grace ( $E G, \mathrm{~V}, 247-8$; XII, 295-6). Pascal's analysis of the proposition that Christ died for all human beings is also pretty close to that of Barcos (EG VII, 261-2). But, unlike Barcos, he does not distinguish senses in which the proposition can be upheld and those in which it cannot. To be precise, Pascal says that 'Dieu a envoyé Jésus-Christ pour sauver [...] ceux qu'ils a choisis et prédestinés [...], qu'il n'y a que ceux-là à qui il ait voulu absolument mériter le salut par sa mort' (261-2). Though the 'absolument' registers the kind of nuances we find in Barcos's analysis, and there appears to be no substantial difference between their positions, Pascal's formulation does not show the same concern to negotiate a way round the condemnation of the Fifth Proposition. In a sense, therefore, it highlights by contrast what I take to be the tactical aspect of Barcos's text.

The conception of grace as delectation is likewise common to both authors, as is the analysis of the compatibility with freedom of grace so conceived.

L'homme n'agissant jamais avec plus de joie \& avec plus de plaisir, \& par consequent avec plus de volonté que lors que la Grace forme en lui la bonne volonté, que lorsqu'elle fond la dureté de son cœur par la douceur de son amour, que lorsque par sa force toute-puissante elle opére en lui le consentement, que lorsqu'elle l'incline, qu'elle le pousse, qu'elle de détermine, qu'elle le ravit, qu'elle l'emporte, \& qu'elle l'aplique à vouloir le bien; jamais aussi il n'a une plus véritable \& plus entiére liberté. (Barcos, 225)

Compare the reference in the Écrits sur la grâce to:

la grâce médicinale, la grâce de Jésus-Christ, qui n'est autre chose qu'une suavité et une délectation dans la loi de Dieu, répandue dans le cœur par le Saint-Esprit, qui non seulement égalant, mais surpassant encore la concupiscence de la chair, remplit la volonté d'une plus grande délectation dans le bien, que la concupiscence ne lui en offre dans le mal, et qu'ainsi le libre arbitre, charmés par les douceurs et par les plaisirs que le Saint-Esprit lui inspire, plus que par les attraits du

\footnotetext{
${ }^{31}$ On the possibility of the commandments, see EG I-V, 211-50, X, 283-7: on the Council of Trent in particular see especially $E G$ I, 211-17 and IV, 235-40.
} 
péché choisit infailliblement lui-même la Loi de Dieu par cette seule raison qu'il y trouve plus de satisfaction et qu'il y sent sa béatitude et sa félicité.

De sorte que ceux à qui il plaît à Dieu à donner cette grâce, se portent d'eux-mêmes par leur libre arbitre à préférer infailliblement Dieu à la créature. Et c'est pourquoi on dit indifféremment ou que le libre arbitre s'y porte de soi-même par le moyen de cette grâce, parce qu'en effet il s'y porte, ou que cette grâce y porte le libre arbitre, parce que toutes les fois qu'elle est donnée, le libre arbitre s'y porte infailliblement. (EG, XI, 290)

But in the Provinciales, Pascal gives what may appear as a richer analysis of delectation:

Selon ce grand saint [Augustine] [...] Dieu change le cœur de l'homme par une douceur céleste qu'il y répand, qui surmontant la délectation de la chair, fait que l'homme sentant d'un côté sa mortalité et son néant, et découvrant de l'autre la grandeur et l'éternité de Dieu, conçoit du dégoût pour les délices du péché qui le séparent du bien incorruptible, et trouvant sa plus grande joie dans le Dieu qui le charme, il s'y porte infailliblement de lui-même, par un mouvement tout libre, tout volontaire, tout amoureux. (Les Provinciales, XVIII, OC, I. 800-1)

Barcos carefully distinguishes between graces of the mind, which do not act on the will, and graces of the will, which, as their name suggests, do (172). By, on the other hand, incorporating a cognitive element into his presentation of efficacious grace, so that not only do we respond to the delectation it communicates, but we are aware of ourselves as so responding, as consenting to this grace rather than merely succumbing to it, Pascal makes more intelligible the reconciliation of grace and liberty, and the claim that we ourselves can in some sense own the acts we perform under the influence of grace.

One observation in conclusion that applies to both writers, and perhaps to the whole body of doctrine they are defending. Pascal makes the brilliant observation about Molinism that, unlike Calvinism, it has the attraction of appealing to common sense (EG, VII, 26o). Or rather, to quote his exact term, 'flattering' it. We must instead prefer the unflattering truths of Augustine's doctrine. In philosophy as in theology, we are often challenged by the most powerful thinkers to abandon our attachment to common sense. But in such cases the question arises to what extent we should suspend feelings of incredulity or even revulsion. Revulsion is certainly part of both writers' reactions to Calvinism: Barcos speaks of 'les impietez \& les blasphémes qu'a vomi (sic) en ces derniers siécles Calvin le dernier des hérétiques' (267); Pascal calls Calvinism an 'opinion épouvantable', 'injurieuse à Dieu et insupportable aux hommes' (EG VII, 260). Both of them insist that Augustine's doctrine of predestination and reprobation is quite different from Calvin's: whereas the latter teaches that God's will, prior to any foreseen sin, is the sole cause of reprobation, and that some human beings were created in order to be damned $(267-8)$, the former, says Barcos, regards Original Sin as the cause of 
reprobation (268-9). There is a substantial difference here, between supralapsarian and infralapsarian conceptions of predestination. Moreover, for the Jansenists, although election is an altogether gratuitous act of mercy, unrelated to any foreseen merit, reprobation is in virtue of foreseen demerit (including that of Original Sin): thus Barcos says: 'Dieu ne prédestine les mechans à la mort éternelle qu'après la prévision de leurs pechez, \& principalement du peché originel' (233). The Calvinists, on the other hand, impioiusly and blasphemously make God responsible for reprobation also: before any prevision of their sins, certain human beings have been created to be damned (267-8).

Pascal makes the point at more length:

Ils [les disciples de saint Augustin] entendent que Dieu a séparé cette masse toute également coupable et tout entière digne de damnation, qu'il en a voulu sauver une partie par une volonté absolue fondée sur sa miséricorde toute pure et gratuite, et que laissant l'autre dans la damnation où elle était et où il pouvait avec justice laisser la masse entière, il a prévu ou les péchés particuliers que chacun commettrait, ou au moins le péché originel dont ils sont tous coupables, et qu'ensuite de cette prévision il les a voulu condamner. (EG, VII, 261)

Or, as he says more succinctly, 'l'Église prétend que la prédestination vient de la volonté absolue de Dieu et la réprobation de la prévision du péché' $(E G, \mathrm{XV}, 310)$. The Calvinists, on the other hand, ascribe both predestination and reprobation to the absolute will of God. In other words, whereas 'l'Église pose que la volonté de Dieu est la source du salut et que la volonté des hommes est la source de la damnation', the Calvinists make God's will the source of both salvation and damnation (EG, XV, 310).

Calvinism, then, the implication is, does not deal in unpalatable truth, but in revolting falsehoods. Unlike the doctrine of Augustine. Take his view of perseverance, as expounded by both Barcos and Pascal. We might suppose that if a person has been justified, and has lived a morally good Christian life, and afterwards falls away, that this is in a key sense their own fault: they have squandered the graces they were offered. After all, Barcos points out that the will is always mutable, and thus may wish not to persevere (Exposition, 174). But for Augustine this is only superficially true, as Barcos explains elsewhere: one may be granted grace, yet not perseverance in grace (208). It is not enough to say that God predestined grace, with which human beings can do good works, and persevere in the good if they wish (238-9).$^{32}$ God gives the gift of perseverance to some, not to others, because he wants the elect, and not the reprobate, to obtain glory (248). He may allow the elect to fall so as to humiliate them, but even their sins are turned to good. Whereas the reprobate may do good works, but they incur a greater punishment when they abandon virtue and good works and plunge into vice through the wickedness of their will-which they infallibly will, since they don't receive the gift of perseverance, and so they are damned (254). If one asks how it is that God will genuinely

\footnotetext{
${ }^{32}$ Barcos thus rejects the scholastic distinction between predestination to grace and predestination to glory (pp. 239-40). For Augustine, there is only one predestination.
} 
remit sin and eternal punishment by Baptism, and yet refuse the gift of perseverance, without which one is bound to fall back into sin and its penalty (271-2), the answer is to hand:

Le peché originel par qui tous les hommes devant Dieu ne sont qu'une masse de perdition, lui donne un droit souverain de vie \& de mort sur eux; de les laisser tous périr, s'il le veut; de leur donner tant \& si peu de graces qu'il lui plaît. (272)

Essentially the same teaching is propounded by Pascal, but in different terms, in his stark doctrine of the 'double délaissement'. ${ }^{33}$ If some of the justified abandon God, there is a terrible sense in which he abandons them first. For he does not give them the gift of perseverance. True, Christ said: 'Ask, and it will be given to you; search, and you will find; knock, and the door will be opened to you' (Matthew 7. 7). So those who pray for grace will never be denied. But prayer itself requires a gift of grace: it is not altogether within our power. And God sometimes withholds the grace of prayer from individuals hitherto in a state of grace and obedience to His will. Unable to pray, they will inevitably turn away from God. But it was God's denial of the grace of prayer that caused their abandonment of him. Why they are cast away, we cannot know: but it cannot be as a result of some action on their part, for if a person in a state of grace could choose, of his or her own initiative, to abandon God, then the efficacy of grace would depend on the human will, and we would be back in semi-Pelagianism. ${ }^{34}$ Pascal argues that salvation and damnation result in a sense from God's will and in a sense from man's; but that God's will is the dominant one, since it is the cause of man's will, rather than being caused by it. Where one will is dominant, the other subordinate, the action is to be ascribed to the former rather than the latter (VII, 259). On this showing, to say that X, who was for a time among the justified, but who has fallen from grace, has done so by his own fault, and is damned for the sins he will commit as a result, is to make man's will only the subordinate cause of reprobation. The dominant cause is God's decision to deny him perseverance. The mechanism of reprobation is no doubt different in this account and in that of the Calvinists. But in both cases it seems hard to deny that God is responsible. In this light the substantive difference between Jansenist theology and that of Calvinism is less clear-cut than the Jansenists argue. ${ }^{35}$

\footnotetext{
${ }^{33}$ On this 'double abandonment' (by God of man, and man by God) see EG VI, 251-6; VII, 262; VIII, 264-71; IX, 278-83; XII, 296-8. According to Philippe Sellier, Pascal probably found the doctrine in the work of Amable de Bourzeis: Sellier stresses the importance of the notion for Pascal, existential as well as theological) (Pascal et saint Augustin, pp. 353-4; cf. pp. 257-8, 274). There is a discussion of the Écrits sur la grâce in Moriarty, 'Grace and Religious Belief in Pascal', in Nicholas Hammond (ed.), The Cambridge Companion to Pascal (Cambridge: Cambridge University Press, 2003), pp. 144-61.

${ }^{34}$ It is, though, in a sense their own fault: because if they had wanted to persevere, they would have been able to do so (EG VII, 262): even if in the last analysis it was God that wanted them not to want to persevere.

${ }^{35}$ Leszek Kolakowski is one scholar who tends to minimize the difference between Jansenism and Calvinism (God Owes Us Nothing: A Brief Remark on Pascal's Religion and on the Spirit of Jansenism (Chicago and London: University of Chicago Press, 1995). His views are discussed in
} 
Moriarty, Early Modern French Thought: the Age of Suspicion (Oxford: Oxford University Press, 2003), 37-40. 